\title{
Таврические чтения 2013. Актуальные проблемы парламентаризма: история и современность. Международная научная конференция, Санкт-Петербург, Таврический дворец, 11-12 декабря 2013 г. Сборник научных статей / Под редакцией А. Б. Николаева: В 2-х частях. СПб.: ЭлекСис, 2014. Ч. 1.360 с.; Ч. 2. 180 с.
}

\begin{abstract}
Аннотация. Рецензируется сборник статей, подготовленный по результатам работы международной научной конферениии «Актуальные проблемы парламентаризма: история и современность», состоявщейся в декабре 2013 2. Конферениия прошла в рамках ежегодных «Таврических чтений», организатором которых является Центр истории парламентаризма при Межпарламентской ассамблее государств - участников Содружества Независимых Государств. Особое значение на конферениии получила тема взаимоотношений парламента и монархии в России начала ХХ в.: рассматривалисъ вопросы восприятия Думы в великокняжеской среде и в кругах русских правых, а также роль монархии в конституиионных проектах русских либералов. Большое внимание также уделялось проблеме соотношения политической мотивачии и парламентской риторики различных сил, представленных в дореволюиионной Думе. Разбирался вопрос о роли российского парламента в подготовке и победном завершении Февральской револючии 1917 г. Отдельная секиия была посвящена источниковедческим и археографическим проблемам истории российского парламентаризма. На основе представленных докладов были подготовлены научные статьи, включенные в настоящее издание. В сборнике впервъе появились особые разделы, связанные сорганизаиией думских выборов в Российской империи, а также с парламентской традииией дальнего зарубежья (опубликовано несколько докладов по истории британского парламента от его зарождения до середины ХХ в.).
\end{abstract}

Ключевые слова: Российскал империя, парламентаризм, конституиионализм, Дом Романовых, Государственнал дума, Государственный совет, либералы, кадетскал партия, черносотенцы, Февральскал револючия.

Abstract. The reviewed collection of papers was put together from the presentations made during the international conference "Current Problems of Parliamentarism: History and Modernity" that took place in December 2013. The conference was held within the framework of the annual "Tauride Readings" and was organised by the Centre of the History of Parliamentarism at the Interparliamentary State Assembly - members of the Commonwealth of Independent States. At the conference, the topic of the relationship between parliament and monarchy in Russia at the beginning of the 20th century was addressed, which included questions regarding the perception of the Duma by the Grand Prince environment and by right-wing Russian circles, as well as the role of the monarchy in the constitutional projects of Russian liberals. Particular attention was also devoted to the question of the correlation between political motivation and parliamentary rhetoric of the various sides represented in the pre-Revolutionary Duma. The conference also discussed the role of the Russian parliament in the preparation and victorious completion of the February Revolution of 1917. A separate section was devoted to the source study and archeographic problems concerning the history of Russian parliamentarism. The scientific articles were prepared on the basis of the presented papers and included in these volumes. This collection introduces for the first time special sections related to the organisation of Duma elections in the Russian Empire, as well as the parliamentary traditions of the far abroad (including a few papers on the history of the British parliament from its inception to the middle of the 20th century).

Key words: Constitutional Democratic Party, liberals, State Council, State Duma, House of Romanov, constitutionalism, parliamentarism, Russian Empire, Black Hundreds, February Revolution. 


\section{Исторический журнал: научные исследования № 4 (28) • 2015}

DOI: $10.7256 / 2222-1972.2015 .4 .17033$

2007 г. в здании Таврического дворца в Петербурге, где до 1917 г. располагалась Государственная дума Российской империи, а ныне находится Межпарламентская ассамблея государств - участников Содружества Независимых Государств, ежегодно проходит международная научная конференция, посвященная актуальным проблемам парламентаризма. Организатором конференции выступает Центр истории парламентаризма при МПА СНГ. В декабре 2013 г. состоялись VII Таврические чтения, по результатам которых вышел настоящий сборник научных статей.

Первый раздел сборника посвящен кардинальной проблеме взаимоотношений парламента и монархии в России начала XX столетия. В статье С. В. Куликова, подготовленной на основе доклада, озвученного на пленарном заседании конференции, рассматривается восприятие Думы великими князьями. Статья имеет ярко выраженную полемическую заостренность. Как отмечает исследователь, в целом они стремились к упрочению парламентской традиции, а в период Первой мировой войны сделали в этом направлении еще один шаг и способствовали попыткам создания парламентарного строя. Однако накануне событий 2-3 марта 1917 г. думцы «слепо пошли на поводу у республиканцев», не соединили усилия с великокняжеской фрондой в борьбе за «ответственное министерство» и потому упустили «уникальный и абсолютно беспроигрышный шанс» $[1,36]$. Такой вывод кажется излишне смелым, с учетом того что реальный политический вес великих князей в начале 1917 г. был слишком мал, о чем в политических кругах было хорошо известно. Наоборот, именно «республиканцы» с момента победы в столице революции приобрели большое влияние. Думцы пошли с ними на союз, потому что других серьезных партнеров в борьбе с самодержавием у них просто не было. Что касается самих великих князей, то радикализация их настроений говорит не о прогрессивности этого круга, а о степени его кризиса и деморализованности. Отсутствие сплоченности вокруг престола в период войны и социального кризиса могло стать и стало лишь одним из поводов к революции, но не могло быть основой для политической реформы. Цитируемая С. В. Куликовым фраза Б. Н. Чичерина о прогрессивной роли самодержавия $[1,19]$ лишь подчеркивает это суждение. Появление великокняжеской фронды стало настоящим самоубийством Дома Романовых.
Та же органическая зависимость от самодержавия была характерна и для правых сил, что хорошо демонстрирует в своей статье И. В. Омельянчук. Создание законодательного парламента неумолимо вело консервативные силы к превращению в одну из думских сил, в конечном счете - в правую оппозицию, использующую в своей борьбе весь арсенал средств парламентской деятельности. Ликвидация Думы, о которой мечтала значительная часть правых, могла лишь ослабить их влияние и усилить объект их дежурной критики - бюрократию. Если правые в целом органично вписались в думские реалии, то положение радикальных либералов в рамках самодержавно-парламентской системы оказалось еще менее однозначным - как раз в силу обозначенной С. В. Куликовым «республиканской» альтернативы. Попытку выстроить либеральную модель отношений парламентаризма и монархии освещает в своей статье Д. В. Аронов. На примере прописанных в конституционном проекте С. А. Муромцева (1905 г.) полномочий монарха исследователь показывает умеренный и компромиссный характер этого документа, что не было типичным для представителей формировавшейся кадетской партии, настроенных на возможность превращения Думы в Учредительное собрание.

В настоящем сборнике впервые появился раздел, непосредственно посвященный думским выборам. А. Д. Гронский анализирует предвыборную риторику белорусских националистов и показывает ее противоречия: в частности, русские правые и польские помещики оказались записаны в единый «черносотенный» лагерь, что совершенно противоречило политическим реалиям $[1,79]$. В целом, реконструкция идеологических конструктов различных политических сил является крайне перспективным направлением изучения для исследователей истории российского парламентаризма.

Самым объемным традиционно стал раздел сборника, посвященный созданию и «внутренней кухне» Государственной думы. А. В. Новиков освещает вопрос отношения рабочих к созданию Государственной думы в период Первой русской революции. Манифест 17 октября был воспринят в патриархально-социалистическом ключе: как призыв к обобществлению имущества, уравнению сословий и т. п. Парламентаристские лозунги распространялись в рабочей среде как революционерами, так и их собственными работодателями. Велик был уровень абсентеизма 


\section{Рецензии, библиография}

DOI: $10.7256 / 2222-1972.2015 .4 .17033$

при выборах как в I, так и во II Думу (которую, как известно, социалистические партии не бойкотировали). К думским роспускам и изменению избирательного закона в 1907 г. рабочие отнеслись нейтрально [1, 117-121]. Напротив, сама Дума зачастую демонстрировала борьбу за интересы рабочих. Ф. А. Селезнев проанализировал речи кадетского оратора по экономическим вопросам А. И. Шингарева и показал, что в них не было отстаивания интересов буржуазии. Развивая выводы, ранее сформулированные в соответствующей монографии [2, 163-168], и полемизируя с оппонентами, исследователь делает вывод о том, что кадеты буржуазной партией не являлись. В данном случае важно также проследить мотивы политической риторики депутата. Следовало бы реконструировать и «второй план» кадетской активности, уже не связанный с «цветами красноречия»: поведение кадетов в комиссиях, лоббирование ими интересов конкретных промышленных групп. Значение разнообразных политических мотивов хорошо заметно и на примере обсуждения других тем. Н. А. Портнягина освещает детали обсуждения вопроса об амнистии в Первой думе: доминировавшие в ней кадеты рассчитывали на амнистию как на средство пополнения рядов политических активистов для усиления давления на власть, но вместе с тем ими отвергалась идея осуждения Думой революционного терроризма.

Проблеме парламентаризма и революции посвятил свою статью А. Б. Николаев. Частные совещания членов Государственной думы в марте 1917 г. он рассматривает как форму народного представительства. Впервые в историографии вопроса реконструированы все состоявшиеся в течение первого месяца революции заседания. Историк приходит к выводу, что совещания были вполне работоспособными и заменяли собой Государственную думу [1, 264]. При этом высокие полномочия совещаний признавались Временным правительством. В качестве доказательства приводится заявление А. Ф. Керенского и доклад, озвученный в совещании министром земледелия А. И. Шингаревым [1, 247]. Отметим, что никакой официальной правительственной позиции все же заявлено не было. Стоит также учесть, что представительство в России было двухпалатным, а о возобновлении работы Государственного совета речи не велось. Совещания думцев все же имели именно частный характер: они не подразумевали участия всех фракций, кворума и прочих элементов регламента. А. Б. Николаев считает, что Дума не подчинилась указу от 25 февраля о приостановке сессии [1, 242], но считать так у нас нет никаких формальных оснований. Частное совещание 27 февраля, избравшее Временный комитет, актом неподчинения не являлось. Временный комитет не был предусмотрен думским наказом, являлся органом неформальным, его создание было связано с революцией и крахом законного порядка в столице. Создание новых революционных органов власти - в первую очередь Временного правительства - сразу привело к тому, что комитет оказался оттеснен на обочину политических событий [3, 307-308, 315-317, 324-330].

Рассматривая историю Государственной думы, исследователи не могли обойти стороной и Государственный совет. В статье А. Н. Мичурина освещается вопрос участия членов Государственного совета в Прогрессивном блоке в августе 1915 г. Программа блока была подписана представителями трех групп этой законодательной палаты (а также внепартийным М. А. Стаховичем), однако это не означало автоматического включения в состав блока всех членов этих объединений. Представители Государственного совета на августовских переговорах с думцами рассматривали программу как список предложений для правительства, который в случае его одобрения Советом министров позволил бы привлечь к межпалатному объединению новых участников [4, 26].

В лучших традициях петербургской историографии целый раздел сборника посвящен думскому источниковедению. Несколько статей касаются археографического описания архивных фондов, связанных с историей Государственной думы. Традиционным стал раздел, посвященный современной истории парламентаризма в странах СНГ. Наоборот, новшеством этого сборника явилось включение в него целого ряда статей, связанных с историей британского парламентаризма от его зарождения до середины XX в. Возможность сравнения думской практики с реалиями Государственного совета, современным опытом стран ближнего зарубежья, а также британской традицией позволяет резко расширить научные рамки и придать выводам более основательный характер.

Хотелось бы отметить еще один немаловажный аспект прошедшей конференции. В ее рамках был проведен конкурс аспирантских и студенческих работ по истории парламентаризма. Работы победителей конкурса были опубликованы в настоящем сборнике. 


\section{Исторический журнал: научные исследования № 4 (28) • 2015}

DOI: $10.7256 / 2222-1972.2015 .4 .17033$

\section{Библиография:}

1. Таврические чтения 2013. Актуальные проблемы парламентаризма: история и современность. Международная научная конференция, Санкт-Петербург, Таврический дворец, 11-12 декабря 2013 г. Сборник научных статей / Под редакцией А. Б. Николаева: В 2-х частях. СПб.: ЭлекСис, 2014. Ч. 1. 360 с.

2. Селезнев Ф. А. Конституционные демократы и буржуазия (1905-1917 гг.). Нижний Новгород: Издательство Нижегородского госуниверситета, 2006. $228 \mathrm{c.}$

3. Гайда Ф. А. Либеральная оппозиция на путях к власти (1914 - весна 1917 г.). М.: РОССПЭН, 2003. 432 с.

4. Таврические чтения 2013. Актуальные проблемы парламентаризма: история и современность. Международная научная конференция, Санкт-Петербург, Таврический дворец, 11-12 декабря 2013 г. Сборник научных статей / Под редакцией А. Б. Николаева: В 2-х частях. СПб.: ЭлекСис, 2014. Ч. 2.180 с

\section{References (transliterated):}

1. Tavricheskie chteniya 2013. Aktual'nye problemy parlamentarizma: istoriya i sovremennost'. Mezhdunarodnaya nauchnaya konferentsiya, Sankt-Peterburg, Tavricheskii dvorets, 11-12 dekabrya 2013 g. Sbornik nauchnykh statei / Pod redaktsiei A. B. Nikolaeva: V 2-kh chastyakh. SPb.: ElekSis, 2014. Ch.1.360 s.

2. Seleznev F. A. Konstitutsionnye demokraty i burzhuaziya (1905-1917 gg.). Nizhnii Novgorod: Izdatel'stvo Nizhegorodskogo gosuniversiteta, 2006. $228 \mathrm{~s}$.

3. Gaida F. A. Liberal'naya oppozitsiya na putyakh k vlasti (1914 - vesna 1917 g.). M.: ROSSPEN, 2003. $432 \mathrm{~s}$.

4. Tavricheskie chteniya 2013. Aktual'nye problemy parlamentarizma: istoriya i sovremennost'. Mezhdunarodnaya nauchnaya konferentsiya, Sankt-Peterburg, Tavricheskii dvorets, 11-12 dekabrya 2013 g. Sbornik nauchnykh statei / Pod redaktsiei A. B. Nikolaeva: V 2-kh chastyakh. SPb.: ElekSis, 2014. Ch. 2. $180 \mathrm{~s}$ 